newborn infants. J Pediatr 76.237

20. Quie PG, Mills EL 1979 Bactericidal and metabolic function of polymorphonuclear leukocytes. Pediatrics [suppl.] 64:719

21. Repo H, Jokipii AM, Leirisalo M, Kosunen TU 1980 Leukocyte motility in the newborn: Determination of spontaneous movement is essential in the in vitro assessment of neutrophil chemotaxis. Clin Exp Immunol 40.620

22. Santosham M. Moxon ER 1977 Detection and quantitation of bacteremia in childhood. J Pediatr 91:719

23. Shigeoka AO, Charette RP, Wyman ML, Hill HR 1981 Defective oxidative metabolic responses of neutrophils from stressed neonates. J Pediatr 98:392

24. Shigeoka AO, Santos JI, Hill HR 1979 Functional analysis of neutrophil granulocytes from healthy, infected, and stressed neonates. J Pediatr 95:454

25. Steigbigel RT, Lambert LH, Remington JS 1974 Phagocytic and bactericidal properties of normal human monocytes. $\mathrm{J}$ Clin Invest 53:131

26. Stroobant J, Harris MC, Cody CS, Polin RA, Douglas SD 1983 Bactericidal capacity for group B streptococci of neutrophils from children with chronic granulomatous disease. Infect Immun 39:966-969

27. Van Epps DE, Goodwin JS, Murphy S 1978 Age-dependent variations in polymorphonuclear leukocyte chemiluminescence. Infect Immun 22:57

28. Wright WC, Ank BJ, Herbert J, Stiehm ER 1975 Decreased bactericidal activity of leukocytes of stressed newborn infants. Pediatrics 56:579

29. The authors thank Dr. J. Campos for technical advice, and Barbara Erwins and Mary Swayne for editorial assistance.

30. This study was supported by The Thrasher Research Fund, the Kroc Foundation, and the National Institutes of Health, Department of Human Services Grants 1 R01 HL 27068 and 1 P01 NS 17752.

31. Requests for reprints should be addressed to: Dr. Richard A. Polin, Division of Neonatology, The Children's Hospital of Philadelphia, 34th Street and Civic Center Boulevard, Philadelphia, PA 19104-.4399.

32. Received for publication September 1, 1983.

\title{
Reduction of Phagocyte Adherence by Nephritic Sera: Relation to Complement Activation
}

\author{
C. FREDERIC STRIFE(43) AND EDWARD J. RULEY \\ From the Children's Hospital Research Foundation and the Department of Pediatrics, University of Cincinnati \\ College of Medicine. Cincinnati, Ohio [C.F.S.J and Children's Hospital National Medical Center and the \\ Department of Pediatrics, George Washington School of Medicine, Washington, D.C. [E.J.R.] USA
}

\begin{abstract}
Summary
Phagocytes isolated from either normal donors or from patients with poststreptococcal (P-SGN), lupus erythematosus (SLEGN), or membranoproliferative (MPGN) glomerulonephritis showed normal adherence to glass (PAg) after incubation in normal human serum (NHS), but was reduced after incubation in patient serum. Low PAg was the consequence of incubation of normal phagocytes with the earliest available sera from all $22 \mathrm{P}$ SGN patients, 28 of 37 SLE-GN patients, 19 of 25 patients with MPGN type I, all 10 with types II and III, and all 5 with nephritis associated with chronic bacteremia. Low C3 and decreased PAg were related by regression analysis in sera from patients with P-SGN $(P<0.001)$, SLE-GN $(P<0.005)$, and MPGN $(P<0.001)$ type I. In patients with P-SGN and one patient with nephritis associated with chronic bacteremia, complement levels and PAg returned to normal in parallel with clinical improvement. In vitro, PAg was reduced by NHS treated with either zymosan or bovine serum albumin (BSA)-anti-BSA complexes but neither BSA-anti-BSA complexes or zymosan, previously incubated in NHS, reduced PAg. PAg was normal in serum deficient in $\mathrm{C} 4$ or $\mathrm{C} 5$ unless treated with zymosan.
\end{abstract}

\section{Abbreviations}

P-SGN, poststreptococcal glomerulonephritis

SLE-GN, systemic lupus erythematosus glomerulonephritis

MPGN, membranoproliferative glomerulonephritis

BSA, bovine serum albumin

NHS, normal human serum

PAg, phagocytic adherence to glass

RC4 GP, C4-deficient guinea pig serum

$\mathrm{RC5}$, congenitally C5-deficient human plasma

Previous investigators have described abnormalities in the function of phagocytes (polymorphonuclear leukocytes and monocytes) obtained from the circulation of patients with a variety of glomerulonephritides. These abnormalities include: (a) decreased chemotactic responsiveness of phagocytes from patients with P-SGN, SLE-GN, MPGN, and other nephritides (5, 21,22 ), (b) defective phagocytosis by cells from patients with SLE-GN $(2,23,31,32,41)$, and (c) decreased adherence to glass by both phagocytes in whole blood from patients with P-SGN (26) and monocytes incubated in serum from patients with SLEGN (31). In vitro studies of phagocytes from some of these patients suggest that the impaired cellular function results from factor(s) present in nephritic serum $(2,5,21-23,31,32,41)$ related to the complement system $(22,26)$ and that resolution of these phagocyte abnormalities may reflect lessening of disease activity $(22,26,31)$.

Phagocyte adherence has been studied using a variety of in vitro techniques which substitute negatively changed surfaces for vascular endothelium (25). Adherence of phagocytes to vascular endothelium has been shown to be prerequisite for many normal functions including diapedesis (1), response to chemotactic stimuli (3), and, in most instances, phagocytosis (39). The present study investigates the effect of serum from children with glomerulonephritis on the ability of isolated autologous or normal donor phagocytes to adhere to a negatively charged surface. These studies suggest that phagocyte adherence is reduced in the presence of nephritic serum as the result of a humoral phenomenon probably produced by generation of a factor(s) when $\mathrm{C} 3$ is activated.

\section{MATERIALS AND METHODS}

Study Subjects. Control population. The control population consisted of 30 healthy adult laboratory personnel, 20 children with various nonrenal disorders, and 32 children with a variety of known renal disorders. All 82 control individuals had normal 
serum levels of $\mathrm{C} 1 \mathrm{q}, \mathrm{C} 4, \mathrm{C} 3, \mathrm{C} 5$, properdin, and factors $\mathrm{B}, \mathrm{I}$, and $\mathrm{H}$.

Patient population. The diagnosis of P-SGN was made in 22 children based on previously published criteria $(26,28)$. Twentyone had an initial low C3 level in serum obtained within 10 days of disease onset which returned to normal in all 13 who had follow-up measurements. The renal biopsy from the one patient with normal C3 levels was consistent with P-SGN (28). A diagnosis of SLE-GN was made in 37 patients who fulfilled the diagnostic criteria established by the American Rheumatism Association (33). All had nephritis as evidenced by the presence of proteinuria and/or hematuria and all but eight were receiving prednisone when initially studied. All 35 patients with MPGN had one or more renal biopsies $(30,38)$ and 15 were receiving prednisone in an alternate day regimen when initially studied. A clinical diagnosis of nephritis secondary to chronic bacteremia was made in five patients based on the combination of (a) bacteremia, (b) presence of a ventriculoatrial shunt or valvular heart disease, and (c) proteinuria and hematuria.

Laboratory Methods. Phagocyte adherence assay. Phagocytes were isolated by a modification of the method of Weissmann $e t$ al. (37). Twenty $\mathrm{ml}$ of heparinized whole blood was mixed with $5 \mathrm{ml} 5 \%$ dextran $\mathrm{T}-70$ in $0.9 \% \mathrm{NaCl}$ (Pharmacia Fine Chemicals, Piscataway, $\mathrm{NJ}$ ) and $5 \mathrm{ml}$ citrate-glucose-adenine solution (34). The erythrocytes were allowed to sediment for $1 \mathrm{~h}$ at $26^{\circ} \mathrm{C}$ and the leukocyte-rich plasma was removed. Phagocytes were pelleted by centrifugation and contaminating erythrocytes were removed by hypotonic lysis with $20 \mathrm{ml}$ of distilled water. Thirty $\mathrm{ml} \mathrm{BSA}$, $0.01 \%$ in $0.9 \% \mathrm{NaCl}, \mathrm{pH} 7.4$, was added after $30 \mathrm{sec}$. The suspension was recentrifuged and decanted and the cell pellet was washed once again with BSA solution. The cell pellet was resuspended in gelatin-veronal buffer, $\mathrm{pH} 7.4$, containing 0.15 $\mathrm{mM}$ calcium and $1 \mathrm{mM}$ magnesium $\left(\mathrm{GVB}^{++}\right)$and the cell concentration was determined. Typical yields approximated 60 $70 \%$. Approximately $80-90 \%$ of the isolated phagocytes were polymorphonuclear leukocytes and $>97 \%$ were viable as measured by trypan blue dye exclusion.

The washed phagocytes were radiolabeled by incubation with $2 \mu \mathrm{Ci}$ of chromium-51 (Amersham Corp, Arlington Heights, IL) per $10^{6}$ cells for $1 \mathrm{~h}$ at $37^{\circ} \mathrm{C}(12)$. Free chromium was removed by three washes with phosphate-buffered saline, $\mathrm{pH} 7.4$ and, when necessary, the cell suspension was filtered through sterile gauze to remove cell clumps or strands. The cell pellet was resuspended in $\mathrm{GVB}^{++}$and phagocyte concentration and viability were determined. An aliquot of the cell suspension was centrifuged and the supernatant was counted to ensure less than $1 \%$ free ${ }^{51} \mathrm{Cr}$ remained. The final phagocyte concentration was adjusted to between 2 and $4 \times 10^{6}$ cells $/ \mathrm{ml}$ by dilution in $\mathrm{GVB}^{++}$. For some experiments, phagocytes were isolated from patients' blood (after receiving informed consent) in the same manner.

Phagocyte adherence was determined by mixing $0.1 \mathrm{ml}$ washed, normal, labeled phagocytes (or, in specific instances, labeled patient phagocytes) with $0.1 \mathrm{ml}$ of either autologous serum or test serum in a disposable glass test tube $(12 \times 75 \mathrm{~mm}$, Fisher Scientific Co., Pittsburgh, PA). All sera from patients and controls were either fresh or stored at $-70^{\circ} \mathrm{C}$ for less than 1 month. The suspensions were mixed and incubated for $30 \mathrm{~min}$ at $37^{\circ} \mathrm{C}$ with occasional shaking and the nonadherent cells were removed by three washings with $\mathrm{GVB}^{++}$. The number of counts remaining in the test tubes which contained autologous serum and cells was considered $100 \%$ of control. Counts remaining in test tubes in which cells were incubated with test serum were divided by the $100 \%$ of control counts and adherence is expressed as percentage of control. All assays were performed in triplicate.

Activation of complement in vitro. Aliquots of NHS, RC4 GP serum (obtained from guinea pigs kindly provided by Dr. Michael Frank, Bethesda, MD), and human plasma congenitally deficient in C5 (RC5) (kindly provided by Dr. Henry Gewurz, Chicago, IL) were incubated with $4 \mathrm{mg} / \mathrm{ml}$ zymosan for $30 \mathrm{~min}$ at $37^{\circ} \mathrm{C}$. In one experiment, BSA-anti-BSA immune precipitates
(27) were incubated with NHS in a similar manner. The activated serum was separated from zymosan or immune precipitates by centrifugation prior to incubation with phagocytes. Both zymosan and immune precipitates lowered the $\mathrm{B}$ antigen of $\mathrm{C} 3$ in NHS by greater than $60 \%$ (36).

Complement quantitation. Serum levels of C1q, C2, C4, C3, $\mathrm{C} 5$, and factors $\mathrm{B}, \mathrm{I}$, and $\mathrm{H}$ were measured by radial immunodiffusion $(22,29,40)$.

Statistical methods. Regression coefficients were calculated by the method of least squares and other comparatives calculated by $\chi^{2}$ using Yates' correction.

\section{RESULTS}

Decreased phagocyte adherence induced by serum rather than cellular phenomena. Isolated, radiolabeled phagocytes from either normal individuals or patients with either P-SGN or SLEGN adhere to glass equally well when incubated with fresh NHS (Table 1). In contrast, both normal and patient phagocytes adhere to glass poorly when incubated with nephritic serum. A similar pattern of PAg was observed with phagocytes isolated from a patient with MPGN (not shown).

Decreased PAg induced by nephritic sera. Adherence of normal, radiolabeled phagocytes incubated with sera from control subjects or from patients with nephritis is shown in Figure 1. PAg in normal adult serum ranged from $83-125 \%$ of control (mean $\pm 2 \mathrm{SD}=100 \pm 20 \%$ of control). Serum from children with nonrenal disorders was associated with normal or increased PAg. However, serum from three of six children with juvenile rheumatoid arthritis gave low adherence. These three children had clinically active, seropositive juvenile rheumatoid arthritis at the time of study. Normal or elevated PAg was produced by 28 of 32 sera from patients with normocomplementemic renal disorders. The patients whose sera gave low adherence had IgAIgG mesangial nephropathy (1), focal glomerulosclerosis (1), and membranous nephropathy (2).

All initial serum samples from 22 patients with recent onset P-SGN produced low PAg. Similarly, PAg was reduced by 28 of $37(76 \%)$ of the first available serum specimens from patients with SLE-GN, 19 of 25 sera from patients with type I MPGN, all sera from patients with types II and III MPGN, and all initial sera from five patients with the nephritis secondary to chronic bacteremia.

Relation of phagocyte adherence to complement protein levels. PAg was low in each of the 22 initial serum samples from patients with P-SGN, while levels of $\mathrm{C} 3$ and properdin were low in all but one and C5 levels, measured in 9, were low in 6 (Fig. 2). Significant correlations between PAg measurements and levels of $\mathrm{C} 3(n=55 ; r=0.7 ; P<0.001)$, properdin $(n=41 ; r=0.5$; $P<0.001)$, and $\mathrm{C} 5(n=27 ; r=0.5 ; P<0.01)$ were suggested by serial measurements in 13 patients which showed PAg to

Table 1. Adherence of phagocytes from normal subjects or patients with nephritis incubated with normal or nephritic serum*

\begin{tabular}{lc}
\hline \multicolumn{1}{c}{ Cell and serum sources } & $\begin{array}{c}\text { Counts } \\
\text { adhered (\%) }\end{array}$ \\
\hline Normal donor + autologous NHS & 28 \\
P-SGN patient + NHS & 22 \\
Normal donor + P-SGN & 8 \\
P-SGN patient + autologous P-SGN & 5 \\
& \\
Normal donor + autologous NHS & 48 \\
SLE patient + NHS & 50 \\
Normal donor + SLE-GN & 9.5 \\
SLE patient + autologous SLE-GN & 2.5 \\
\hline
\end{tabular}

* Use of different cell sources in these experiments necessitates expression of results as a percentage of total counts added to the glass test tube. 


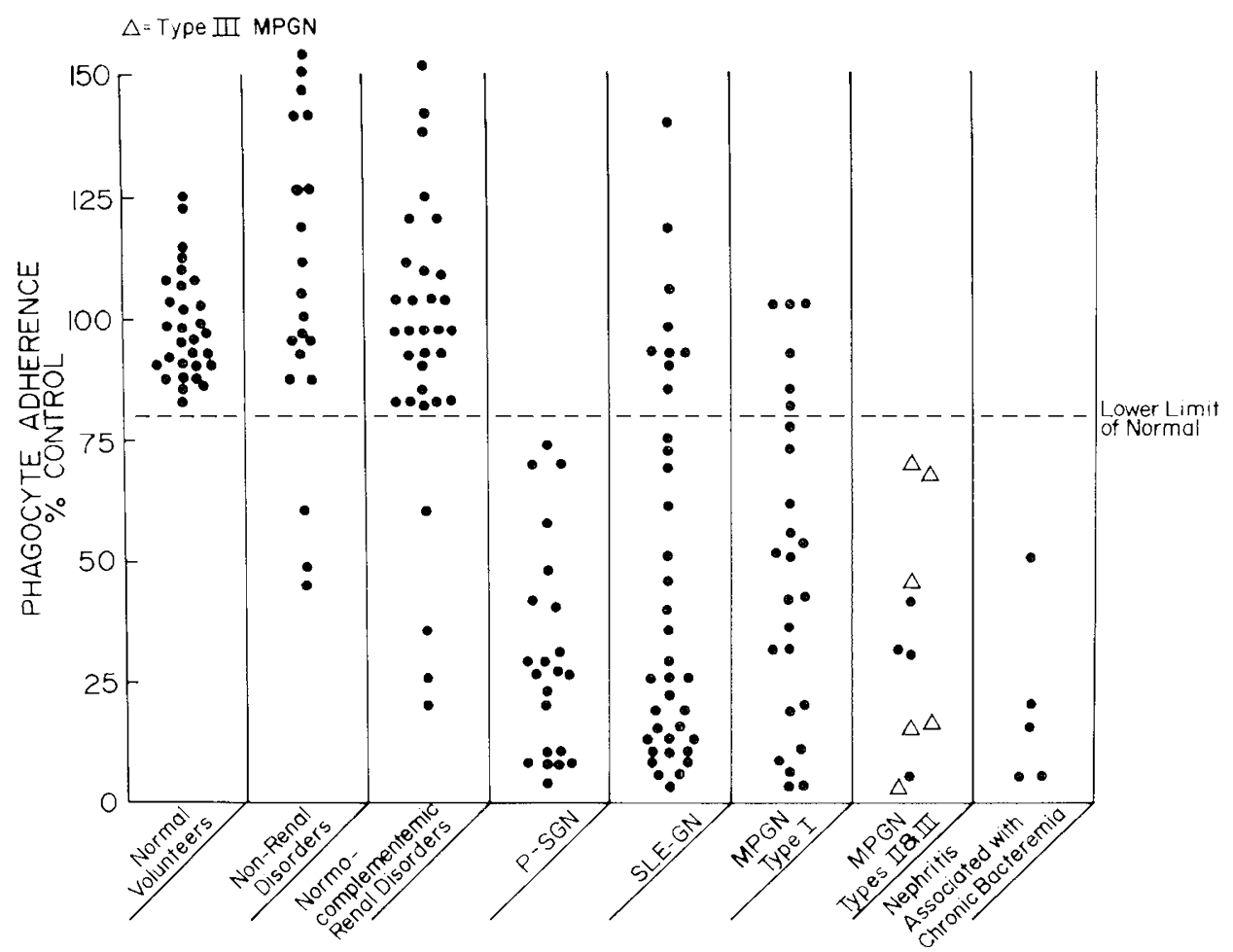

Fig. 1. Glass adherence of phagocytes from normal donors incubated in sera from the following groups: 1) normal adult volunteers, 2) normocomplementemic children with nonrenal disorders (diabetes mellitus, rheumatic fever, hemolysis, arthritis, infectious diseases), 3) normocomplementemic children with known renal disorders (focal glomerulosclerosis, membranous nephropathy, polycystic kidney disease, postural proteinuria, idiopathic nephrotic syndrome, IgA mesangial nephropathy, hemolytic uremic syndrome, Henoch-Schönlein purpura nephritis, cystinosis, obstructive uropathy, Goodpasture's syndrome, idiopathic rapidly progressive nephritis), and 4) children with nephritides commonly associated with hypocomplementemia. All values plotted are from the first available serum sample.

- Normocomplementemic Patient Values

Fig. 2. Phagocyte adherence and complement component levels in 22 initial P-SGN serum samples. The normal range for each measurement is shaded. from the one normocomplementemic patient. Levels of factor $\mathrm{B}$ in 9 patients and $\mathrm{C} 2, \mathrm{I}$, and $\mathrm{H}$ in 7 patients were normal and are not shown.

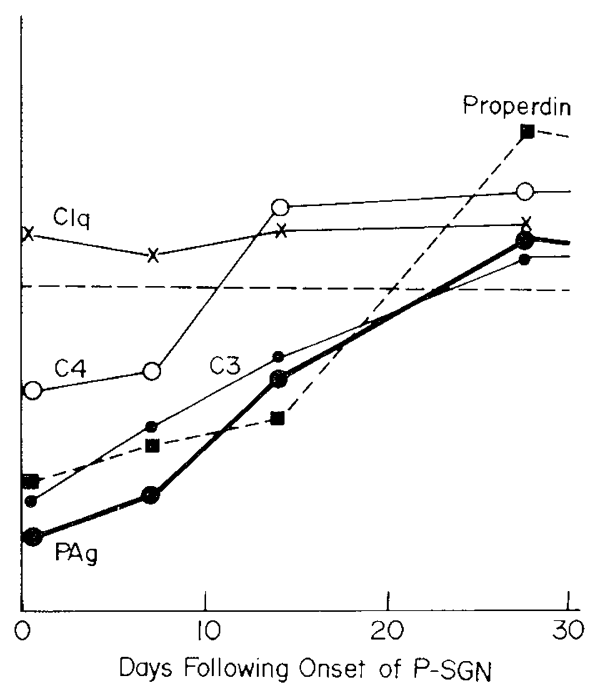

Fig. 3. Serial measurements of serum Clq, C4, C3, properdin, and PAg in a typical patient with P-SGN. The vertical scales have been adjusted so that the dashed horizontal line is the lower limit of normal (mean $-2 \mathrm{SD}$ ) for all five determinations. Serum C5 levels were not measured.

return to normal in parallel with $\mathrm{C} 3$, properdin, and $\mathrm{C} 5$ levels (Fig. 3).

The PAg mediated by the first available serum specimen from 37 SLE-GN patients was low in 28 (76\%) (Fig. 4). Nine of those with low adherence had normal levels of all measured complement proteins while the remaining 19 contained one or more low complement component levels. Six of the 9 sera with normal PAg had normal complement component levels while 2 had low 
640

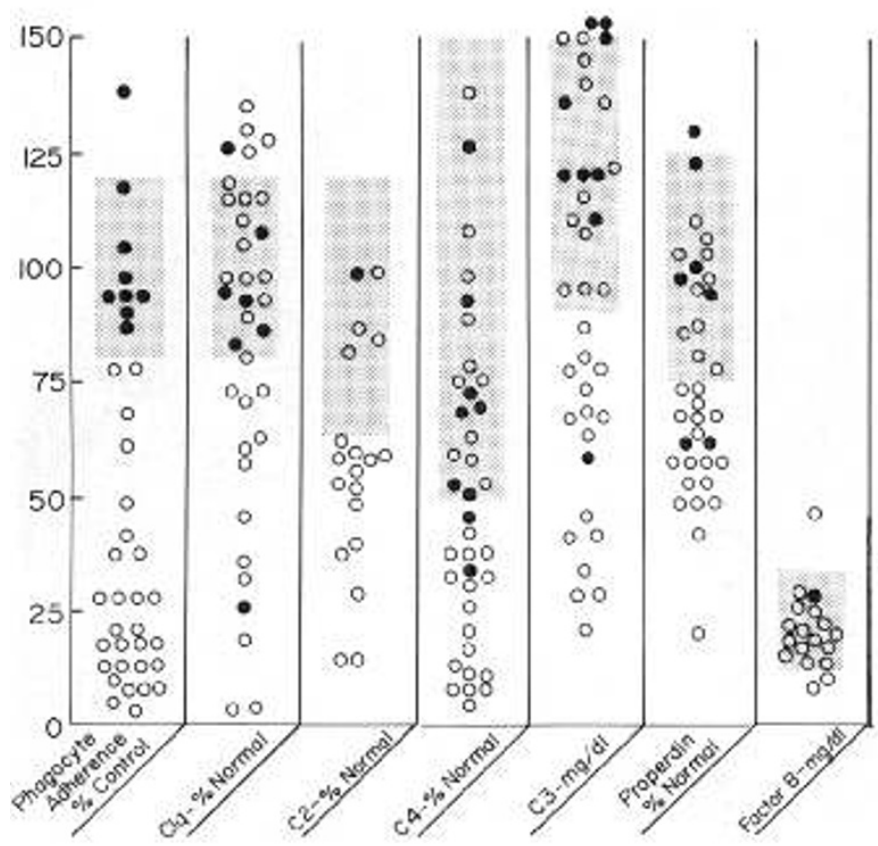

Fig. 4. PAg and complement component levels in the 37 earliest available serum samples from patients with SLE-GN. The normal range for each measurement is shaded. O, values from sera giving low PAg: values from sera giving normal PAg. Serum C5. I, and $\mathrm{H}$ levels were measured in 18 patients and were normal and are not shown.

C4 and properdin levels and 1 had both low C1q and C3 levels. Regression analysis suggested a moderate relationship only between levels of $\mathrm{C} 3$ and PAg $(n=37 ; r=0.49 ; P<0.005)$.

One hundred fifteen serum samples were available from the 37 patients with SLE-GN. Low PAg, induced by 94 of these samples, was associated with a low $\mathrm{C} 3$ level in $49(P<0.005)$ Whereas low PAg was produced by 49 of 51 sera with low $\mathrm{C} 3$ levels, 45 of 64 sera with normal $\mathrm{C} 3$ levels also resulted in reduced PAg. Regression analysis of levels of PAg versus levels of complement proteins suggested a relationship only with levels of $\mathrm{C} 3(n=115: r=0.30 ; P<0.01)$ and factor $\mathrm{B}(n=67 ; r=$ $0.43 ; P<0.001)$. The data were inadequate to assess the relationship between disease activity and PAg levels.

In patients with MPGN, as shown in Figure 5, low PAg was induced by the earliest serum available from 19 of 25 patients with type I, all 4 with type II, and all 6 with type III. Adequate numbers of measurements for statistical analysis were available only from patients with type I MPGN. In these patients, regression analysis revealed a significant correlation between levels of PAg and C $3(n=25 ; r=0.81 ; P<0.001), \mathrm{C} 2(n=17 ; r=0.47$; $P<0.05)$, and properdin $(n=22 ; r=0.49 ; P<0.02)$.

Low PAg was induced by all five serum samples from patients with nephritis associated with chronic bacteremia. All had low C3 levels. Three had low C4 levels and two had low properdin levels. In one patient, complement component levels and PAg returned to normal in parallel following antibiotic treatment. Long term follow-up of the other four patients or of the patients with MPGN is not adequate to assess a relation between disease activity and PAg.

Relationship of immune complexes to PAg. The effect of immune complexes formed in vitro on $\mathrm{PAg}$ was investigated due to the common association of circulating immune complexes with the nephritides whose sera has been shown to induce low PAg. Incubation of normal phagocytes with BSA-anti-BSA immune precipitates (or aggregated $\mathrm{IgG}$ ), suspended in $\mathrm{GVB}^{++}$ with or without prior incubation in NHS, did not alter PAg. In contrast. NHS in which BSA-anti-BSA immune precipitates had been incubated caused a marked reduction in adherence.

Effect of in vitro complement activation, complement inactivation. or reduction of complement component levels on PAg. As shown in Table 2, incubation of normal donor phagocytes with autologous serum, C4-deficient guinea pig serum, or C5-deficient human serum resulted in normal PAg. Treatment of these sera with zymosan prior to incubation with phagocytes resulted in very low PAg. Zymosan harvested after incubation in NHS caused no reduction of PAg.

Inactivation of the $\mathrm{C} 3 \mathrm{~b}$ amplification loop in NHS by heating at 50 or $56^{\circ} \mathrm{C}$ (for as little as $4 \mathrm{~min}$ ) or addition of heparin, hydrazine, or divalent cation chelators resulted in impaired $\mathrm{PAg}$. However, mixing increasing amounts of $0.9 \% \mathrm{NaCl}$ with NHS to lower complement levels did not alter PAg.

\section{DISCUSSION}

The association of reduced phagocyte adherence with glomerulonephritis was first suggested for SLE by Svensson (31) who showed that monocytes cultured in the presence of serum ad-

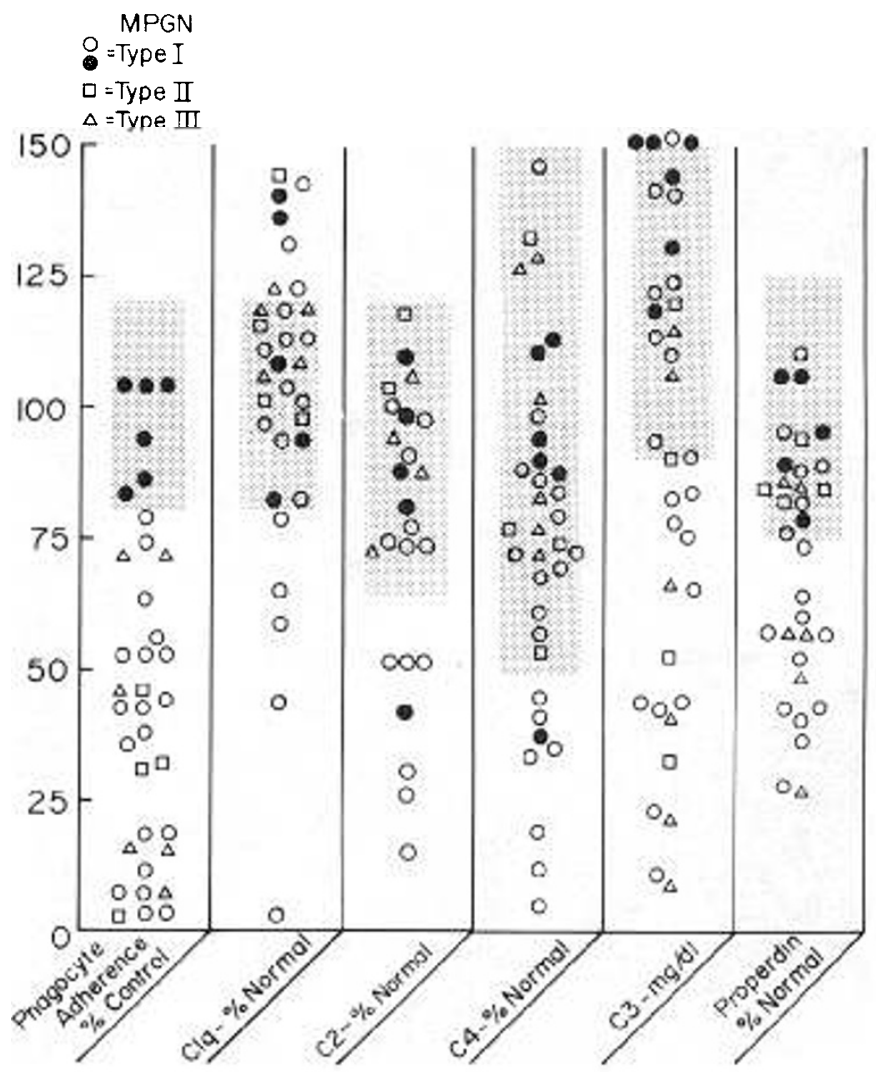

Fig. 5. PAg and complement component levels in the earliest available serum samples from 25 patients with type I, 4 with type II, and 6 with type III MPGN. The normal range for each measurement is shaded. Open s.mbols are from sera giving low PAg as in Figure 4. In serum from patients with type I MPGN, low levels of factor B and I were present in 2 and low $\mathrm{H}$ was found in 3 (not shown).

Table 2. Adherence of donor phagocytes to glass following incubation with complement-activated sera

\begin{tabular}{lc} 
Cell and serum sources & $\begin{array}{c}\% \text { Adherence } \\
\text { of } \\
\text { control }\end{array}$ \\
\hline Normal donor + autologous serum & 100 \\
Normal donor + RC4 GP serum & 92 \\
Normal donor + RC5 human serum & 103 \\
Normal donor + autologous Txz & 10 \\
Normal donor + RC4 GP Txz & 13 \\
Normal donor + RC5 human $\mathrm{Tx}_{\mathrm{Z}}$ & 17 \\
Normal donor + zymosan in $\mathrm{GVB}^{++}$ & 90
\end{tabular}

* $\mathrm{T}_{\mathrm{z}}$, treated with zymosan. 
hered poorly to glass when compared to monocytes cultured in the presence of NHS. Subsequently, Ruley et al. (26) observed decreased glass adherence of phagocytes in whole blood from patients with P-SGN. In the present report, sera from patients with P-SGN, SLE-GN, and MPGN were associated with decreased adherence of phagocytes whether the cells were autologous or isolated from normal donors. These same normal or "nephritic" phagocytes when incubated with NHS adhered normally. As suggested for SLE by Svensson (31), the altered adherence was thus the result of a serum factor(s).

The relationship between PAg and glomerulonephritis appears to extend to disease activity. Decreased adherence induced by serum from patients with P-SGN clearly paralleled both the disease course and the rise of $\mathrm{C} 3, \mathrm{C} 5$, and properdin levels in those patients who were originally hypocomplementemic. A similar observation was made by Ruley et al. (26). Additionally, low C4, C3, and PAg levels returned to normal in parallel with antibiotic therapy in one patient with nephritis associated with a chronically infected ventriculoatrial shunt. Although the relationship between disease activity and reduced adherence for patients with SLE-GN and MPGN remains unclear due to insufficient long term follow-up, Svensson (31) suggested a relationship between monocyte adherence and disease activity in three patients with SLE.

The mechanism for decreased PAg after incubation with nephritic serum is poorly understood yet appears from the excellent correlation of PAg with $\mathrm{C} 3$ levels in patients with P-SGN, SLEGN, and MPGN in the present report to be related to complement. A number of investigators have shown complement to be necessary for normal PAg when phagocytes are incubated with serum. Treatment of NHS by chelation of divalent cations $(3,4$, $9,13,17,25)$ or heating $(3,13,17,25)$ results in decreased adherence. In addition, magnesium has been shown to preferentially restore adherence of cells incubated in chelated serum $(4,10,13)$. These observations suggest that in NHS heat-labile, divalent cation-dependent complement proteins are necessary for normal PAg and the demonstrated magnesium dependency indicates that an intact $\mathrm{C} 3 \mathrm{~b}$ amplification loop is necessary. This was further shown in the present study by demonstrating norma adherence of phagocytes incubated with RC4 or RC5 serum but impaired PAg when the C3b amplification loop of either of these sera was activated by zymosan. These results suggest that, unlike phagocyte aggregation (8), C5a is not responsible for the altered adherence induced by complement-activated serum. The observation that PAg is not reduced by diluting NHS with $0.9 \% \mathrm{NaCl}$ indicates that complement proteins are not required for adherence. It is more likely that NHS contains an inhibitor of PAg which is normally controlled by an intact $\mathrm{C} 3 \mathrm{~b}$ feedback system. Alteration in the function of the $\mathrm{C} 3 \mathrm{~b}$ amplification loop, whether by in vitro manipulations or by in vivo activation, results in impaired PAg. This hypothesis will require further investigation.

Our results appear to contrast with those from earlier reports $(7,19,20,24)$ which suggested enhancement of phagocyte adherence by complement-activated serum but there are significant differences in technique. Craddock et al. (7), using heat-inactivated normal plasma as a control rather than NHS as used in the present study, noted increased phagocyte adherence to plastic following incubation with zymosan-activated plasma. Our experiments (unpublished) using serum are similar to observations by Craddock et al. (7) and have consistently shown more impairment of PAg by heat-inactivated serum than by zymosanactivated serum. Using nylon wool columns, enhancement of adherence of phagocytes in complement-activated whole blood has been observed $(19,24)$ but McGillen and Phair $(20)$ have shown this to be due to nonspecific trapping of aggregated phagocytes in the nylon wool columns. These experimental variables were avoided in the present report by using normal phagocytes reconstituted in autologous serum for controls and a glass adherent surface which avoids nonspecific trapping of aggregated phagocytes.
Although complement activation in vitro and low $\mathrm{C} 3$ levels in vivo are clearly related to induction of low adherence as shown herein, the finding of extremely low PAg induced by many nephritic serum samples from normocomplementemic patients suggests that serum factor(s) other than complement, but perhaps related to the complement system, may be responsible for low PAg. The presumed relation of immune complexes to the nephritides associated with decreased $\mathrm{PAg}$ suggested to us the possibility that circulating complexes represented the common contributor to impaired adherence. However, PAg was not alltered when normal phagocytes were incubated with preformed immune complexes which had previously been incubated in NHS, indicating that the complexes were not responsible for lowering PAg.

Another possible contributor to decreased PAg was the prednisone therapy used daily by 29 of our patients with SLE-GN and every other day by 15 patients with MPGN. MacGregor (18, 19) has shown that corticosteroids may decrease phagocyte adhesiveness. However, in our experience with serum from patients with idiopathic nephrotic syndrome or postrenal transplantation receiving daily or alternate day prednisone, no impairment in $\mathrm{PAg}$, as measured by the technique used in the present study, has been observed.

The significance of decreased PAg in the pathogenesis of glomerulonephritis remains obscure. The altered ability of phagocytes to adhere to glass may be reflected in vivo by altered endothelial adherence. Systemic complement activation, such as occurs with immune complex diseases, appears to paralyze phagocytes (15). Unable to adhere to the glomerular capillary endothelium and phagocytose immune complexes lodged there, phagocytes may damage the glomerular basement membrane with lysosomal enzymes $(14,15)$ released in response to locally deposited complement by-products $(6,35)$. Alternately, the observed impaired phagocyte adherence might be related to leukocyte aggregation which may also occur in association with systemic complement activation (16). Aggregated leukocytes may transiently plug glomerular capillaries and release damaging lysosomal enzymes as has been proposed for the pulmonary leukocyte sequestration syndrome (16). Lastly, altered phagocyte adherence may not be at all related to the glomerular inflarnmatory reaction. Rather, altered adherence may change the host's ability to clear circulating immune complexes, thereby enhancing their glomerular capillary deposition.

\section{REFERENCES AND NOTES}

1. Allison F, Lancaster MG, Crosthwaite JL 1963 Studies on the pathogenesis of acute inflammation. $V$. An assessment of factors that influence in vitro the phagocyte and adhesive properties of leukocytes obtained from rabbit peritoneal exudate. Am J Pathol 43:775

2. Brandt L, Hedberg H 1969 Impaired phagocytosis by peripheral blood granulocytes in systemic lupus erythematosus. Scand J Haematol 6:348

3. Bryant RE. DesPrez RM, VanWay MH, Rogers DE 1966 Studies on human leukocyte motility. I. Effects of alterations in $\mathrm{pH}$, electrolyte concentration, and phagocytosis on leukocyte migration, adhesiveness, and aggregation. Exp Med 124:483

4. Bryant RE, Sutcliff MC 1972 A method for quantitation of human leukocyte adhesion to glass. Proc Soc Exp Biol Med 141:196

5. Clark RA, Kimball HR, Decker JL 1974 Neutrophile chemotaxis in systemic lupus erythematosus. Ann Rheum Dis 33:167

6. Cochrane CG. Hawkins D 1968 Studies of circulating immune complexes. III Factors governing the ability of circulating complexes to localize in blood vessels. J Exp Med 127:137

7. Craddock P. Fehr J, Dalmasso A, Brigham K. Jacob H 1977 Hemodialysis leukopenia: pulmonary vascular leukostasis resulting from complement activation by dialysis cellophane membranes. J Clin Invest 59:879

8. Craddock PR, Hammerschmidt DE, Moldow CF, Yamada O, Jacob H 1979 Granulocyte aggregation as a manifestation of membrane interactions with complement: possible role in leukocyte margination, microvascular occlusion and endothelial damage. Semin Hematol 16:140

9. Fehr J, Jacob HS 1977 In vitro granulocyte adherence and in vivo margination: two associated complement-dependent functions. J Exp Med 146:641

10. Fenn WO 1922 The adhesiveness of leukocytes to solid surfaces. J Gen Physiol $5: 143$

11. Forristal J, litaka K. Vallota EH, West CD 1977 Correlations between serum factor $\mathrm{B}$ and $\mathrm{C} 3 \mathrm{~b}$ inactivator levels in normal subjects and in patients with 
infections, nephrosis and hypocomplementaemic glomerulonephritis. Clin Exp Immunol 28:6

12. Gallin JI, Clark RA, Kimball HR 1973 Granulocyte chemotaxis: an improved in vitro assay employing ${ }^{51} \mathrm{Cr}$-labeled granulocytes. J Immunol 110:233

13. Garvin JE 1961 Factors affecting the adhesiveness of human leukocytes and platelets in vitro. J Exp Med 114:51

14. Henson PM 1971 Interaction of cells with immune complexes: adherence, release of constituents and tissue injury. J Exp Med 134:114s

15. Jacob HS 1978 Granulocyte-complement interaction, a beneficial antimicrobial mechanism that can cause disease. Arch Intern Med 138:461

16. Jacob HS, Craddock PR, Hammerschmidt DE, Moldow CF 1980 Complement-induced granulocyte aggregation: an unsuspected mechanism of disease. N Engl J Med 302:789

17. Kvarstein B 1969 A methodological study of human leukocyte adhesiveness to glass beads. Scand J Clin Lab Invest 23:259

18. MacGregor RR 1976 The effect of anti-inflammatory agents and inflammation on granulocyte adherence: evidence for regulation by plasma factors. Am J Med 61:597

19. MacGregor RR 1977 Granulocyte adherence changes induced by hemodialysis, endotoxin, epinephrine and glucocorticoids. Ann Intern Med 86:35

20. McGillen JJ, Phair JP 1979 Adherence, augmented adherence, and aggregation of polymorphonuclear leukocytes. J Infect Dis 139.69

21. Norman ME, Miller ME 1973 Spontaneous chemotaxis in patients with glomerulonephritis and the nephrotic syndrome. J Pediatr 83:390

22. Norman ME, Miller ME 1974 Spontaneous chemotaxis in acute glomerulonephritis: demonstration of a positive correlation with disease activity. $J$ Pediatr 85:20

23. Notani GW. Kenyon AJ, Zurier RB 1976 Altered neutrophile function induced by serum from patients with systemic lupus erythematosus. In; Friedman $\mathrm{H}$ Escobar MR, Reichard SM (eds): Advances in Experimental Biology, Reticuloendothelial System in Health and Disease, Vol 73, Part B. New York, Plenum Press, pp 147-154

24. O'Flaharty JT, Craddock PR, Jacob HS 1978 Effect of intravascular complement activation on granulocyte adhesiveness and distribution. Blood 51:731

25. Penny R, Galton DAG, Scott JT, Eisen V 1966 Studies on neutrophile function. I. Physiological and pharmacological aspects. Br J Haematol 12:623

26. Ruley EJ, Huang S, Plaut J, Morris N 1976 Defective phagocyte adherence in acute post streptococcal glomerulonephritis: clinical and laboratory observations. J Pediatr $89 \cdot 748$

27. Spitzer RE, Stitzel AE, Pauling VL, Davis NC, West CD 1971 The antigenic and molecular alterations of $\mathrm{C} 3$ in the fluid phase during an immune reaction in normal human serum. J Exp Med 134:656

28. Strife CF, McAdams AJ, McEnery PT, West CD 1974 Hypocomplementemic and normocomplementemic acute nephritis in children: a comparison with respect to etiology, clinical manifestation, and glomerular morphology. $J$ Pediatr 84:29

29. Strife CF, McDonald BM, Ruley EJ, McAdams AJ, West CD 1976 Shunt nephritis: the nature of the serum cryoglobulins and their relation to the complement profile. J Pediatr 88:403

30. Strife CF, McEnery PT, McAdams AJ, West CD 1977 Membranoproliferative glomerulonephritis with disruption of the glomerular basement membrane. Clin Nephrol 7:65

31. Svensson BO 1975 Serum factors causing impaired macrophage function in systemic lupus erythematosus. Scand J Immunol 4:145

32. Svensson BO, Hedberg H 1973 Impaired phagocytosis by macrophages in SLE. Scand J Rheumatol 2:78

33. Tan EM, Cohen AS, Fries JF, Masi AT, McShane DM, Rothfield NF, Schaller JG, Talal N, Winchester RJ 1982 The 1982 revised criteria for the classification of systemic lupus erythematosus. Arthritis Rheum 25:1271

34. Tibbling $\mathrm{G} 1970$ Glycerol uptake in leukocytes and thrombocytes. Scand J Clin Lab Invest 26:185

35. Unanue ER, Dixon FJ 1967 Experimental glomerulonephritis: immunological events and pathogenetic mechanisms. Adv Immunol 6:1

36. Vallota EH, Forristal J, Spitzer RE, Davis NC, West CD 1970 Characteristics of a non-complement-dependent $\mathrm{C} 3$-reactive complex formed from factors in nephritic and normal serum. J Exp Med 131:1306

37. Weissmann G, Zurier RB, Spieler PJ, Goldstein IM 1971 Mechanisms of lysozomal enzyme release from leukocytes exposed to immune complexes and other particles. J Exp Med 134:149s

38. West CD 1976 Pathogenesis and approaches to therapy of membranoproliferative glomerulonephritis. Kidney Int 9:1

39. Wood WB 1951 Studies on the cellular immunology of acute bacterial infections. Harvey Lect 47:72

40. Wyatt RJ, McAdams AJ, Forristal J, Snyder J, West CD 1979 Glomerular deposition of complement-control proteins in acute and chronic glomerulonephritis. Kidney Int 16:505

41. Zurier RB 1976 Reduction of phagocytosis and lysozomal enzyme release from human leukocytes by serum from patients with systemic lupus erythematosus. Arthritis Rheum 19:73

42. The authors express their appreciation to Mr. Jeffrey Breslin, Mr. William Punch, and Mrs. Maura Tobler for their technical assistance and to Mrs. Karen Kilgo for her secretarial help.

43. Requests for reprints should be addressed to: C. Frederic Strife, M.D., Division of Pediatric Nephrology, Children's Hospital Research Foundation, Elland and Bethesda Avenues, Cincinnati, OH 45229

44. Received for publication April 18, 1983.

45. Accepted for publication October 18, 1983

\title{
Postheparin Plasma Lipase Activities and Plasma Lipoproteins in Newborn Infants
}

\author{
LIISA ROVAMO, ${ }^{(42)}$ MARJA-RIITTA TASKINEN, TIMO KUUSI, ESKO A. NIKKILÄ \\ CHRISTIAN EHNHOLM, AND KARI O. RAIVIO \\ Children's Hospital and Third Department of Medicine, University of Helsinki, and \\ National Public Health Institute, Helsinki, Finland
}

Summary

We measured blood glucose, serum insulin and apoprotein AI and A-II, and triglycerides and cholesterol contained in serum lipoprotein fractions of $\mathbf{2 4}$ full-term newborn infants who underwent exchange transfusion with heparinized blood for hematological reasons. The values were similar to those previously reported for healthy newborn infants. We also measure lipoprotein and hepatic lipase activities with specific methods. Fifteen minutes after an intravenous heparin bolus of $100 \mathrm{IU} / \mathrm{kg}$, mean lipoprotein lipase activity in infants $(16.0 \mu \mathrm{mol}$ free fatty acids $/ \mathrm{ml} / \mathrm{h})$ was as in adults. In contrast, hepatic lipase activity was significantly higher in infants $(54.3 \mu \mathrm{mol}$ free fatty acids $/ \mathrm{ml} / \mathrm{h})$ than in adults. There was no sex difference in the infant lipase activities. Lipoprotein and hepatic lipase activities were also measured 5 and 15 min after a heparin bolus of 10 and $50 \mathrm{IU} / \mathrm{kg}: 10 \mathrm{IU} / \mathrm{kg}$ released only part of the lipase activities. In addition, the two lipases were measured during the exchange transfusion. Although $92 \%$ of the original infant blood was removed, lipoprotein lipase activity remained constant. In contrast, hepatic lipase activity decreased considerably. In infants, postheparin lipolytic activity is a conventional measure of lipoprotein lipase. Lipoprotein and hepatic 